Vol. 4, No. 2, November 2019, pp. 40-47

ISSN : 2085-4226

\title{
EFIKASI EKSTRAK BABADOTAN (Ageratum conyzoides L.) YANG DITAMBAH SURFAKTAN TERHADAP KUTU DAUN PERSIK (Myzus persicae Sulz.) \\ EFICATION OF BABADOTAN (Ageratum conyzoides L.) EXTRACT WHICH SURFACTANT ADDED TO APHIDS (Myzus persicae Sulz.)
}

\author{
Suhardjadinata, Rakhmat Iskandar, Diah Nurain Suci Ningtiyas \\ Jurusan Agroteknologi Fakultas Pertanian Universitas Siliwangi \\ Jl. Siliwangi No. 24 PO Box 164 Tasikmalaya 46115 \\ Korespondensi : hardja59@yahoo.co.id
}

\begin{abstract}
ABSTRAK
Kutu daun persik (Myzus persicae Sulz) merupakan salah satu jenis hama yang memakan segala jenis tumbuhan (polifag), berkembangbiaknya sangat cepat, serangan hama ini pada cabai dapat menyebabkan kerugian yang cukup besar. Gulma babadotan (Ageratum conyzoides L.) mengandung senyawa metabolit sekunder berupa saponin, flavonoid, alkaloid, minyak atsiri serta tanin berpotensi sebagai insektisida nabati untuk mengendalikan kutu daun persik. Aplikasi pestisida nabati di lapangan sering kurang efektif karena mudah tercuci oleh air hujan, sehingga perlu penambahan bahan perekat (surfaktan) agar lebih efektif. Penelitian ini bertujuan untuk mengetahui efikasi ekstrak babadotan yang ditambah surfaktan untuk mengendalikan kutu daun persik. Penelitian dilaksanakan pada bulan April sampai Juni 2019 di Laboratorium Proteksi Tanaman dan rumah kaca Fakultas Pertanian Universitas Siliwangi Tasikmalaya. Penelitian ini menggunakan Rancangan Acak Lengkap pola faktorial dengan tiga kali ulangan. Faktor pertama adalah konsentrasi ekstrak babadotan yaitu : 0\%,22\%,33\%, dan 44\%. Faktor kedua adalah konsentrasi surfaktan yaitu; $0 \%, 0,025 \%$ dan $0,05 \%$. Hasil penelitian menunjukkan bahwa ekstrak babadotan dengan konsentrasi $44 \%$ ditambah surfaktan dengan konsentrasi $0,05 \%$ efektif mengendalikan hama kutu daun persik dengan persentase kematian $73,33 \%$ pada 72 jam setelah aplikasi.
\end{abstract}

Kata kunci : Babadotan (Ageratum conyzoides L.), Kutu Daun Persik, Surfaktan

\begin{abstract}
Aphids (Myzus persicae Sulz) is a type of pest that eats all types of plants (polyphags), reproducing very quickly. The attack of this pest may couse losses. Ageratum conyzoides L (Billygoat-weed) contains substances are secondary metabolites including saponin, flavonoids, alkaloid, essential oil, and tanin that function as botanical insecticides in aphids control. To increase the effectiveness of Billygoat-weed extract as a botanical pesticides it is need to add surfactant. The aims of this experiments were to determine the efficacy of the Billygoat-weed extract which added surfactant to control aphids. This research was conducted from April to June 2019 at the Plant Protection Laboratory Agriculture Faculty of Siliwangi University Tasikmalaya. this experiment method used a Completely Randomized Design with a factorial pattern and three replications. The first factor is concentration of Billygoat-weed extract, that is: $0 \%, 22 \%, 33 \%$, and $44 \%$. The second factor is treatment with the addition of surfactant concentration, that is ; $0 \%, 0.025 \%$ and $0.05 \%$.
\end{abstract}


The results of this research indicate that Billygoat-weed extract with a concentration of $44 \%$ which added surfactants with a concentration of $0.05 \%$ effective to controlling aphids with percentage of $73.33 \%$ at 72 hours after application.

Keywords : Aphids, Billygoat-weed (Ageratum conyzoides L.), Surfactant

\section{PENDAHULUAN}

Hama kutu daun persik (Myzus persicae Sulz) merupakan salah satu jenis hama yang menyerang segala jenis tanaman budidaya (polifag), terutama pada famili Solanaceae. Serangannya pada tanaman dapat menyebabkan daun keriting dan pucuk daun mengkerut, yang pada akhirnya dapat menurunkan produktivitas tanaman. Untuk itu, perlu dilakukan pengendalian yang intensif. Salah satu cara pengendalian hama yang mendukung sistem pertanian berkelanjutan adalah dengan menggunakan pestisida nabati (Dafrinal, Widiana dan Lusi, 2012).

Babadotan (Ageratum conyzoides L) merupakan salah satu jenis gulma yang mengandung senyawa organik yang berpotensi sebagai biopestisida. Menurut Lumowa (2011), ekstrak daun babadotan mengandung bahan aktif saponin, flavanoid dan polifenol yang dapat mencegah atau menolak hama dan juga dapat menghambat pertumbuhan larva menjadi pupa. Bahan aktif yang terkandung pada babadotan mampu mengganggu peletakan telur dan menghambat penetasan telur serangga, serta mampu menghambat reproduksi serangga betina. Kandungan bahan aktifnya terutama saponin dapat menghambat pertumbuhan larva menjadi pupa (Nurhudiman, 2017).

Dari hasil penelitian Nurhudiman (2017), ekstrak daun babadotan pada konsentrasi $\quad 1 \% \quad$ sampai $5 \%$ dapat menghambat pertumbuhan dan kematian Plutella xylostella. Aplikasi ekstrak daun babadotan pada konsentrasi 1\%, 2\%, 3\%, 4\% dan 5\% dapat membunuh 50\% $P$. xylostella masing masing pada 33,31 jam, 21,09 jam, 20,68 jam, 12,65 jam dan 10,86 jam setelah aplikasi

Keefektifan bahan aktif yang terkandung dalam pestisida nabati seringkali tidak maksimal. Hal ini karena bahan aktifnya memiliki sifat mudah tercuci oleh air hujan. Dengan demikian, untuk meningkatkan keefektifan pestisida nabati perlu ada penambahan zat perekat. Salah satu zat perekat yang digunakan untuk mempertahankan keefektifan pestisida nabati adalah dengan penambahan surfaktan.

Hasil penelitian Yusriah, Hambali dan Dadang (2017) diketahui bahwa formulasi insektisida nabati dari biji mimba yang ditambah surfaktan DEA 8\%, dan $46 \%$ solvesso dalam $30 \mathrm{~g}$ formulasi menghasilkan tegangan permukaan, sudut kontak, dan ukuran droplet lebih baik. Hasil uji formula insektisida nabati tersebut pada skala laboratorium dengan konsentrasi $10 \mathrm{ml} / \mathrm{L}$ pada 4 hari setelah aplikasi menyebabkan kematian sebesar $42 \%$.

Hasil penelitian Agustina, Putri, Fauzana dan Sutikno (2017) diketahui bahwa campuran ekstrak Piper retrofractum dengan Annona squamosa, dan campuran ekstrak 
Aglaia odorata dengan Annona squamosa yang ditambah surfaktan Agristik 0,05\% dan $0,03 \%$ dapat membunuh larva Crocidolomia pavonana sebesar $97,5 \%$ dan $90 \%$ pada pengujian semi lapangan. Penambahan surfaktan dengan konsentrasi $0,05 \%$ pada campuran ekstrak bahan pestisida nabati tersebut dapat meningkatkan kematian larva S. litura sebesar $7,5 \%$ dibandingkan konsentrasi $0,03 \%$. Tujuan dari penelitian ini adalah untuk mengetahui keefektifan ekstrak babadotan dengan penambahan surfaktan sebagai bahan perekat terhadap mortalitas hama kutu daun persik (Myzus persicae Sulz).

\section{BAHAN DAN METODE}

Penelitian dilaksanakan pada bulan April sampai Juni 2019 di Laboratorium Proteksi Tanaman dan rumah kaca Fakultas Pertanian Universitas Siliwangi Tasikmalaya. Bahan yang digunakan dalam penelitian ini adalah kutu daun persik, daun cabai rawit (sebagai pakan kutu daun persik), ektrak babadotan, dan surfaktan (agristik). Penelitian menggunakan Rancangan Acak Lengkap (RAL) pola faktorial. Perlakuan terdiri dari dua faktor yaitu: faktor pertama; konsentrasi ekstrak babadotan terdiri dari: a) kontrol (0\%), 22\%, 33\% dan 44\%. Konsentrasi ekstrak babadotan yang diuji ditentukan berdasarkan hasil analisis probit LC50 ekstrak babadotan yaitu $21,513 \%$ yang dibulatkan menjadi 22\%. Faktor kedua; konsentrasi surfaktan (agristik) terdiri dari : a) kontrol (0\%), b) 0,03\% dan c) $0,05 \%$. Dengan demikian penelitian ini terdiri dari 12 perlakuan yang masing-masing diulang sebanyak tiga kali.

Kutu daun persik diperoleh dari areal pertanaman cabai rawit milik petani di Desa Cinambo Kecamatan Bantarujeg
Kabupaten Majalengka. Kutu daun tersebut dipelihara dan diperbanyak dalam toples yang diberi alas dengan kertas saring dan ditutupi dengan kain tile rapat, diberi makan daun cabai yang segar.

Parameter yang diamati yaitu : 1) jumlah kutu daun persik yang mati dihitung pada 12 , 24, 36, 48, 60 dan 72 jam setelah perlakuan, 2) kecepatan kematian, 3) efikasi adalah efektivitas pestisida terhadap organisme sasaran atau merupakan uji kemanjuran suatu insektisida yang digunakan dalam mengendalikan hama.

\section{HASIL DAN PEMBAHASAN}

\section{Mortalitas kutu daun persik}

Hasil analisis statistik pengaruh ekstrak babadotan dengan penambahan surfaktan terhadap mortalitas kutu daun persik pada 12, 24, 36, 48, 60 dan 72 jam setelah aplikasi dengan menggunakan metode pencelupan daun (leaf dipping method) dapat dilihat pada Tabel 1.

Pada Tabel 1 terlihat bahwa semua perlakuan konsentrasi ekstrak babadotan pada setiap jam pengamatan menunjukkan peningkatan mortalitas kutu daun persik. Dari Tabel tersebut diketahui bahwa ekstrak babadotan berpengaruh terhadap mortalitas kutu daun persik karena pada ekstrak babadotan mengandung senyawa metabolit sekunder diantaranya saponin. Hal ini sesuai dengan pernyataan Kinasih (2013) bahwa saponin berpengaruh terhadap mortalitas serangga dengan cara merusak sel-sel syaraf yang dapat menyebabkan menurunnya nafsu makan dan akhirnya tubuh serangga menjadi melemah. Selain saponin, bahan aktif minyak atsiri pada babadotan juga berpengaruh terhadap mortalitas kutu daun persik, senyawa minyak atsiri yang 
terkandung pada babadotan dapat menghasilkan bau yang tidak disukai oleh serangga sasaran. Sehingga dalam hal ini minyak atsiri sebagai pengusir hama (repellent).

Tabel 1. Pengaruh konsentrasi ekstrak babadotan dan penambahan surfaktan terhadap mortalitas kutu daun persik pada 24, 36, 48, 60 dan 72 jam setelah aplikasi

\begin{tabular}{|c|c|c|c|c|c|}
\hline \multirow{2}{*}{$\begin{array}{c}\text { Waktu pengamatan } \\
\text { (jam setelah aplikasi) }\end{array}$} & \multirow{2}{*}{$\begin{array}{c}\text { Konsentrasi ektrak } \\
\text { babadotan }(\%)\end{array}$} & \multicolumn{3}{|c|}{ Konsentrasi surfaktan (\%) } & \multirow{2}{*}{$\begin{array}{c}\text { Rata- } \\
\text { rata }\end{array}$} \\
\hline & & 0 & 0,03 & 0,05 & \\
\hline \multirow{6}{*}{24} & 0 & 0,0 & 6,7 & 6,7 & $4,4 \mathrm{a}$ \\
\hline & 22 & 10,0 & 13,3 & 10,0 & $11,1 \mathrm{~b}$ \\
\hline & 33 & 13,3 & 10,0 & 20,0 & $14,4 \mathrm{c}$ \\
\hline & 44 & 16,7 & 20,0 & 20,0 & $18,9 \mathrm{~d}$ \\
\hline & Rata-rata & 10,0 & 12,50 & 14,2 & \\
\hline & & $\mathrm{A}$ & A & A & \\
\hline \multirow{6}{*}{36} & 0 & 0,0 & 6,7 & 10,0 & $5,56 \mathrm{a}$ \\
\hline & 22 & 13,3 & 17,0 & 13,3 & $14,6 \mathrm{~b}$ \\
\hline & 33 & 16,7 & 20,0 & 23,3 & $23,3 \mathrm{c}$ \\
\hline & 44 & 23,0 & 26,7 & 33,3 & $33,3 \mathrm{~d}$ \\
\hline & Rata-rata & 13,25 & 17,6 & 20,0 & \\
\hline & & A & $\mathrm{B}$ & $\mathrm{B}$ & \\
\hline \multirow{6}{*}{48} & 0 & 0,0 & 20,0 & 23,3 & $14,4 \mathrm{a}$ \\
\hline & 22 & 20,0 & 30,0 & 26,7 & $25,6 \mathrm{~b}$ \\
\hline & 33 & 36,7 & 36,7 & 40,0 & $37,8 \mathrm{c}$ \\
\hline & 44 & 36,7 & 43,3 & 50,0 & $43,3 \mathrm{c}$ \\
\hline & Rata-rata & 23,3 & 32,5 & 35,0 & \\
\hline & & A & $\mathrm{B}$ & $\mathrm{C}$ & \\
\hline \multirow{6}{*}{60} & 0 & 13,3 & 33,3 & 43,3 & $30,0 \mathrm{a}$ \\
\hline & 22 & 56,67 & 60,0 & 63,3 & $60,0 \mathrm{~b}$ \\
\hline & 33 & 63,3 & 56,7 & 66,7 & $62,2 \mathrm{~b}$ \\
\hline & 44 & 56,7 & 63,3 & 70 & $63,3 \mathrm{~b}$ \\
\hline & Rata-rata & 47,5 & 53,3 & 60,8 & \\
\hline & & A & $\mathrm{B}$ & $\mathrm{C}$ & \\
\hline \multirow{6}{*}{72} & 0 & 13,3 & 36,7 & 43,3 & $31,1 \mathrm{a}$ \\
\hline & 22 & 63,3 & 66,7 & 70,0 & $66,7 \mathrm{~b}$ \\
\hline & 33 & 73,4 & 70,0 & 70,0 & $71,1 \mathrm{bc}$ \\
\hline & 44 & 70,0 & 73,3 & 76,67 & $73,3 \mathrm{c}$ \\
\hline & Rata-rata & 55,0 & 61,7 & 65,00 & \\
\hline & & A & $\mathrm{B}$ & $\mathrm{C}$ & \\
\hline
\end{tabular}

Keterangan : Nilai yang diikuti huruf kecil yang sama arah vertikal dan nilai yang diikuti dengan huruf besar yang sama arah horizontal pada setiap jam pengamatan tidak berbeda menurut uji jarak berganda Duncan pada taraf5\%.

Secara mandiri penambahan surfaktan pada ekstrak babadotan berpengaruh nyata dibandingkan tanpa surfaktan terhadap mortalitas kutu daun persik pada pengamatan 48, 60 dan 72 jam setelah aplikasi. Pegaruh surfaktan terhadap mortalitas kutu daun persik adalah dengan cara memperluas penyebaran ekstrak babadotan pada permukaan daun dan mampu merekatkan ekstrak babadotan pada daun cabai rawit (sumber pakan) sehingga kandungan bahan aktifnya dapat bertahan 
lebih lama. Surfaktan bekerja dengan menurunkan tegangan permukaan karena surfaktan memiliki gugus hidrofilik yang berikatan dengan ekstrak dan gugus hidrofobik yang berinteraksi dengan permukaan daun. Surfaktan mampu memecahkan molekul-molekul air sehingga dapat memperluas dan meratakan penyebaran (Agustina, $d k k, 2017$ ).

Dengan demikian, surfaktan mampu meningkatkan efektifitas ekstrak babadotan dalam mengendalikan hama kutu daun. Konsentrasi ekstrak babadotan yang efektif terhadap kematian kutu daun persik adalah dengan konsentrasi $44 \%$. Sementara penambahan surfaktan yang efektif adalah dengan konsentrasi 0,05.

\section{Kecepatan waktu kematian kutu daun persik}

Kecepatan kematian merupakan variabel pengamatan yang menunjukkan jumlah serangga uji yang mati dalam satuan waktu tertentu. Hasil analisis statistik tidak terdapat interaksi antara ekstrak babadotan dengan surfaktan terhadap kecepatan kematian kutu daun persik. Secara mandiri konsentrasi ekstrak babadotan dan konsentrasi surfaktan berpengaruh terhadap kecepatan kematian kutu daun persik pada 24 sampai 72 jam setelah aplikasi (Tabel 2).
Tabel 2. Pengaruh pestisida nabati ekstrak babadotan dengan penambahan surfaktan terhadap kecepatan kematian kutu daun persik pada 12 sampai 72 jam setelah aplikasi.

\begin{tabular}{|c|c|c|c|c|}
\hline \multirow{2}{*}{$\begin{array}{c}\text { Konsentrsi } \\
\text { ektrak } \\
\text { babadotan } \\
(\%)\end{array}$} & \multicolumn{3}{|c|}{$\begin{array}{c}\text { Konsentrasi surfaktan } \\
(\%)\end{array}$} & \multirow{2}{*}{$\begin{array}{l}\text { Rata- } \\
\text { rata }\end{array}$} \\
\hline & 0 & 0,03 & 0,05 & \\
\hline 0 & 2,7 & 11,0 & 13,0 & 8,9 a \\
\hline 22 & 16,7 & 19,3 & 18,7 & $\begin{array}{c}18,2 \\
b\end{array}$ \\
\hline 33 & 22,0 & 19,7 & 23,0 & $\begin{array}{c}21,6 \\
\mathrm{c}\end{array}$ \\
\hline 44 & 21,3 & 23,0 & 25,3 & $\begin{array}{c}23,2 \\
\mathrm{c}\end{array}$ \\
\hline Rata-rata & $\begin{array}{c}15,7 \\
\mathrm{~A}\end{array}$ & $\begin{array}{c}18,2 \\
\mathrm{~B}\end{array}$ & $\begin{array}{c}20,0 \\
\mathrm{C}\end{array}$ & \\
\hline
\end{tabular}

Keterangan : Nilai yang diikuti huruf kecil yang sama arah vertikal dan nilai yang diikuti dengan huruf besar yang sama arah horizontal tidak berbeda menurut uji jarak berganda Duncan pada taraf $5 \%$

Pada Tabel 2. telihat bahwa aplikasi ekstrak babadotan berpengaruh nyata terhadap kecepatan kematian kutu persik dibandingkan dengan kontrol. Aplikasi ekstrak babadotan konsentrasi $33 \%$ berbeda tidak nyata dengan konsntrasi $44 \%$ terhadap kecepatan kematian kutu daun persik. Aplikasi ekstrak babadotan konsentrasi $44 \%$ menunjukkan tingkat kecepatan kematian yang lebih cepat pada kutu daun persik dibandingkan dengan perlakuan lainnya yang mencapai 23,22 ekor/12 jam.

Babadotan mengandung metabolit sekunder tanin yang diduga mampu merusak sitem pencernaaan pada hama sasaran. Menurut Astriani (2010), tanin bekerja dengan cara merusak sitem metabolisme yang dapat mengganggu aktivitas enzim pencernaan. Semakin tinggi konsentrasi ekstrak babadotan yang diaplikasikan semakin cepat kematian kutu 
daun persik. Hal ini karena semakin tinggi konsentrasi ekstrak babadotan yang diaplikasikan semakin tinggi kandungan bahan bahan aktifnya. Sonia, Siswancipto dan Febrianti (2017) menyatakan bahwa semakin tinggi konsentrasi yang digunakan, maka kandungan senyawa metabolit dalam ekstrak tersebut lebih banyak, sehingga daya racunnya lebih tinggi, sehingga proses kematian hama sasaran akan lebih cepat.

Penambahan surfakan pada ekstrak babadotan dengan berbagai konsentrasi berpengaruh nyata terhadap kecepatan kematian kutu daun persik. Penambahan surfaktan dengan konsentrasi 0,05\% menunjukkan tingkat kematian yang lebih cepat dibandingkan dengan penambahan surfaktan dengan konsentrasi 0,025\%. Surfaktan yang yang ditambahkan pada ekstrak babadotan akan meningkatkan daya rekat dan penyebaran pada daun tanaman. Surfaktan berperan dalam memperluas area penyebaran ekstrak babadotan pada permukaan daun, dengan meratanya ektrak babadotan yang diaplikasikan pada permukaan daun, maka aplikasi ekstak babadotan akan lebih optimal. Surfaktan juga mampu merekatkan pestisida pada permukaan daun sehingga kandungan bahan aktif pada pestisida akan menempel lebih lama pada permukaan daun dan tidak mudah tercuci oleh air (Agustina, dkk., 2017).

\section{Tingkat efikasi}

Berdasarkan Peraturan Menteri Pertanian No:24/Permentan/SR.140/4/2011 Pasal 1 disebutkan bahwa efikasi adalah keefektifan suatu bahan pestisida terhadap organisme sasaran yang didaftarkan berdasarkan pada hasil percobaan lapangan atau laboratorium menurut metode yang berlaku. Nurmansyah (2014) menyatakan bahwa pestisida dinilai efektif, jika nilai efikasinya lebih besar dari $50 \%$. Pada penelitian ini tingkat efikasi ektrak babadotan dan penambahan surfaktan diamati pada 72 jam setelah aplikasi. Hasil analisis statistik tidak terdapat pengaruh interaksi ekstrak babadotan dan penambahan surfaktan terhadap tingkat efikasi pada 72 jam setelah aplikasi, namun secara mandiri baik konsentrasi ekstrak babadotan maupun konsentrasi surfaktan berpengaruh nyata terhadap tingkat efikasi (Tabel 3).

Tabel 3. Pengaruh ekstrak babadotan dan surfaktan tergadap tingkat efikasi untuk mengendalikan imago kutu daun persik pada 72 jam setelah aplikasi

\begin{tabular}{ccccc}
\hline Konsentrsi & \multicolumn{3}{c}{$\begin{array}{c}\text { Konsentrasi surfaktan } \\
\text { ektrak }\end{array}$} & \multicolumn{4}{c}{$(\%)$} & Rata \\
\cline { 2 - 4 } $\begin{array}{c}\text { babadotan } \\
(\%)\end{array}$ & 0 & 0,03 & 0,05 & -rata \\
\hline 0 & 13 & 36 & 43 & $31 \mathrm{a}$ \\
22 & 63 & 67 & 70 & $67 \mathrm{~b}$ \\
33 & 73 & 70 & 70 & $71 \mathrm{c}$ \\
44 & 70 & 73 & 77 & $73 \mathrm{c}$ \\
\hline Rata-rata & 55 & 62 & 67 & \\
& $\mathrm{~A}$ & $\mathrm{~B}$ & $\mathrm{C}$ & \\
\hline
\end{tabular}

Keterangan : Nilai yang diikuti huruf kecil yang sama arah vertikal dan nilai yang diikuti dengan huruf besar yang sama arah horizontal pada berbeda tidak nyata menurut uji jarak berganda Duncan pada taraf $5 \%$.

Pada Tabel 3 terlihat bahwa aplikasi ekstrak babadotan dengan konsentrasi $22 \%$, $33 \%$ dan $44 \%$ berbeda nyata dengan kontrol pada pengamatan 72 jam setelah aplikasi. Aplikasi ekstrak babadotan antara konsentrasi 33\% dengan konsentrasi $44 \%$ menunjukan hasil berbeda tidak nyata terhadap tingkat efikasi.

Aplikasi ekstrak babadotan konsentrasi $22 \%$ pada 72 jam setelah aplikasi sudah 
dapat dikatakan efektif karena sudah mampu mematikan kutu daun persik sebesar $67 \%$. Hal ini karena ekstrak babadotan mengandung senyawa aktif yang mampu mengurangi nafsu makan (antifeedant) serangga yaitu flavonoid. Menurut Gunawan (2017), cara kerja flavonoid adalah dengan masuk kedalam tubuh melalui sistem pernafasan yang kemudian akan menimbulkan penurunan fungsi syaraf serta kerusakan pada sistem pernafasan dan mengakibatkan serangga sasaran tidak bisa bernapas dan tidak memakan daun yang diberi perlakuan, sehingga akhirnya hama akan mati.

Aplikasi ekstrak babadotan dengan konsentrasi $44 \%$ menunjukkan tingkat efikasi terbesar yaitu $73 \%$. Penambahan surfaktan dengan berbagai konsentrasi menunjukkan hasil yang berbeda nyata antara semua perlakuan. Penambahan surfaktan pada ekstrak babadotan dengan konsentrasi $0,05 \%$ mampu meningkatkan tingkat efikasi sebesar $67 \%$.

\section{KESIMPULAN}

Berdasarkan hasil penelitian, maka dapat diambil ke simpulan $\mathrm{s}$ :

1. Tidak terdapat pengaruh interaksi antara ekstrak babadotan dan surfaktan terhadap mortalitas, kecepatan waktu kematian dan tingkat efikasi pada hama kutu daun persik.

2. Aplikasi ekstrak babadotan yang ditambah surfaktan pada daun cabai rawit berpengaruh terhadap mortalitas dan kecepatan waktu kematian kutu daun persik.

3. Ekstrak babadotan dengan konsntrasi $44 \%$ ditambah surfaktan konsentrasi $0,05 \%$ efektif mengendalikan hama kutu daun persik.

\section{DAFTAR PUSTAKA}

Agustina, E. P., H. Fauzana dan A. Sutikno. 2017. Pengaruh Penambahan Surfaktan dalam Ekstrak Daun Sirih Hutan ( Piper aduncum L.) untuk Mengendalikan Ulat Grayak (Spodoptera litura F.) pada Tanaman Kedelai (GlycPine $\max (\mathrm{L}$.) Merril). JOM Faperta UR Vol 4 (1).

Astriani, D. 2010. Pemanfaatan Gulma Babadotan dan Tembelekan Dalam Pengendalian Sitophillus Spp. pada Benih Jagung. Program Studi Agroteknologi Fakultas Agroindustri Universitas Mercu Buana Yogyakarta.

Dafrinal, R.Widiana dan A. Lusi. 2012. Kepadatan Populasi Kutu Daun (Myzus persicae Sulz) dan Predatornya (Monoshillus sexmaculata) pada Tanaman Cabe (Capsicum annum) di Kecamatan Kotoparik Gadang Diateh Kabupaten Solok Selatan. Program Studi Pendidikan Biologi dan Ilmu Pendidikan STKIP PGRI Sumatera Barat.

Gunawan,B. A. 2017. Pengaruh Penggunaan Ekstrak Daun Pepaya (Carica papaya) terhadap Hama Ulat Grayak pada Terong (Solanum melongena). (Online).

Tersedia:http://repository.umy.ac.id/h andle/123456789/16323. Diakses pada Tanggal 22 Juli 2019

Kinasi, I. A. Supriyatna dan R. N. Rusputra. 2013. Uji Toksisitas Ekstrak Daun Babadotan (Ageratum conyzoides Linn.) terhadap Ikan Mas (Cyprinus carpio Linn.) sebagai Organisme Nontarget. Jurnal Biologi Fakultas Sains dan Teknologi UIN Sunan Gunung 
Djati Bandung ISSN : 1979-8911.

Vol.VII (2)

Lumowa, S. V. 2011. Efektivitas Ekstrak Babadotan (Ageratum conyzoides L.) Terhadap Tingkat Kematian Larva Spodoptera litura F. Jurnal Eugenia. Vol. 12 (3).

Peraturan Menteri Pertanian Nomor : 24/Permentan/SR.140/4/2011. Syarat Dan Tata cara Pendaftaran Pestisida.(Online).Tersedia:http://psp. pertanian.go.id/assets/file/2014/Perme ntan\%20No.\%2024\%20Th.\%202011 $\% 20 \operatorname{ttg} \% 20$ Syarat\%20dan\%20Tatacar a\%20Pendaftaran\%20Pestis ida.pdf. Diakses pada Tanggal 22 Juli 2019.

Nurhudiman. 2017. Uji Potensi Daun Babadotan (Ageratum Conyzoides L.) Sebagai Insektisida Botani Terhadap Hama (Plutella xylostella L.) di Laboratorium. Fakultas Pertanian Universitas Bandar Lampung.

Nurmansyah. 2014. Pengaruh Interval Aplikasi dan Waktu Penyemprotan Pestisida Nabati Serai Wangi terhadap Hama Helopeltis antonii pada Tanaman Kakao. Balai Penelitian Tanaman Rempah dan Obat. Bogor.

Sonia, S., T. Siswancipto dan T. Febrianti . 2017. Perbedaan Konsentrasi Dan Jenis Pestisida Nabati Terhadap Plutella xylostella Pada Tanaman Kubis Ungu (Brassica Oleracea L.). JAGROS. ISSN: 2548-7752. Vol.1 (2.

Yusriah, E. Hambali, dan Dadang. 2017. Formulasi Insektisida Nabati Minyak Bungkil Mimba Dengan Surfaktan Dea. Jurnal Teknologi Industri Pertanian ISSN: 0216-3160. Vol. 27 (3):310-317. 